\title{
Herbage Production Following Litter Removal on Alberta Native Grasslands
}

\author{
W.D. WILLMS, S. SMOLIAK, AND A.W. BAILEY
}

\section{Abstract}

Studies were conducted to determine the effects on herbage yield of removing mulch and standing dead plant litter during dormancy for up to 3 or more consecutive years. This information is required to obtain a better understanding of the implications of dormant season grazing on forage production. In 2 studies, mulch and standing litter were harvested at 3 or more annual frequencies from $2 \times 2 \mathrm{~m}$ plots. One study was repeated in both the Fescue Prairie and Mixed Prairie communities and plant response was measured annually as the yield of herbage produced from treated and control plots. The second study was conducted in the Fescue Prairie on 3 sites and designed as a $3 \times 3$ Latin square. The treatments consisted of removing mulch and standing litter, removing and replacing this material, and a control. Estimates were made of the yield, species composition, and morphological characteristics of the grasss. A third study was made, in the Fescue Prairie, by defoliating individual rough fescue (Festuca scabrella Torr. var. major Vasey) plants a single time, at 5 and $15 \mathrm{~cm}$ above ground, and comparing them with a control. Herbage yields decreased as the annual frequency of mulch and litter harvests increased in the Mixed Prairie but not in the Fescue Prairie. In the Mixed Prairie, yields declined to $43 \%$ of the control after 3 years of treatment. Removing mulch and standing litter from rough fescue plants resulted in shorter but a greater number of tillers than in the control. The results were similar after 1 or 3 years of treatment.

Native grasslands in southern Alberta provide relatively good quality forage for fall and winter grazing (Johnston and Bezeau 1962). Although photosynthetic tissue is not removed when plants are harvested during dormancy, their subsequent growth is affected. In the first year after removing mulch and standing dead plant litter of rough fescue (Festuca hallii (Vasey) Piper (Sinton 1980) or bluebunch wheatgrass (Agropyron spicatum (Pursh) Scribn. + Smith) (Sauer 1978, Willms et al. 1980), forage yields decreased while tiller densities increased. However, after 2 consecutive years of removing standing dead plant litter from rough fescue, yields were marginally greater and tiller densities were substantially increased (Sinton 1980).

Plant litter helps conserve soil moisture by reducing soil temperature and evaporation (Weaver and Rowland 1952, Hopkins 1954). However, reduced soil temperatures in spring will delay plant growth (Weaver and Rowland 1952) and may result in reduced herbage yield (Dyksterhuis and Schmutz 1947, Penfound 1964) and in a reduced diversity in the plant community (Weaver and Rowland 1952).

Native grasslands in southern Alberta have evolved with buffalo grazing on the Mixed Prairie in summer and on the Fescue Prairie in winter (Johnston and MacDonald 1967). This would suggest that grasses of the Fescue Prairie should be tolerant of winter grazing. However, the effects of removing mulch and harvesting standing dead plant litter on herbage production have not been examined very extensively. Clarke et al. (1947) reported yields from plots harvested after plant senescence, over a 9-year period, but assumed no effect of removing standing dead plant material

\footnotetext{
Authors are range ecologists, Agriculture Canada, Research Station, Lethbridge, Alberta TIJ 4BI; and professor of range management, Dept. of Plant Science, the University of Alberta, Edmonton T6G 2P5.

The authors are grateful for the statistical advice given by $B$. Schaalje. Technicians B.W. Kesler and R.G. Gschaid assisted with the field work. The study at Kinsella was partly supported by a grant from the Agricultural Research Council of Alberta, Farming for the Future, to Dr. A.W. Bailey.

Manuscript accepted 17 April 1986.
}

and had no control treatment.

These studies were initiated to determine the effects of removing mulch and standing litter during the dormant season on forage production in the Fescue Prairie and Mixed Prairie grasslands.

\section{Materials and Methods}

\section{Site Description}

Two study areas were located on the Fescue Prairie and one on the Mixed Prairie of southern Alberta. One Fescue Prairie site was at the University of Alberta Ranch, Kinsella (150 km SE of Edmonton), and the other at the Agriculture Canada Range Research Substation, Stavely ( $90 \mathrm{~km} \mathrm{NW}$ of Lethbridge). The soils, climate, and vegetation of the Kinsella area have been described by Bailey and Anderson (1978) while the Stavely area was described by Willms et al. (1985). Major differences in the plant communities at 2 Fescue Prairie sites were the associated species and the presence or absence of rhizomes on rough fescue. At Kinsella, the rough fescue is rhizomatous and is a species ( $F$. hallii) distinct from the tufted rough fescue ( $F$. campestris Rydb.; or $F$. scabrella Torr. var. major Vasey) found at Stavely (Looman and Best 1979, Pavlick and Looman 1984). The rhizomatous form is associated with western porcupine grass (Stipa spartea Trin. var. curtiseta Hitchc.) while the tufted form is associated with Parry oat grass (Danthonia parryi Scribn.). The soils at both areas were orthic black chernozemic (Argic Cryoboroll). Precipitation averaged $432 \mathrm{~mm}$ at Kinsella and $614 \mathrm{~mm}$ at Stavely (Table 1). The

Table 1. Precipitation (mm) from April to August during the period of studies at 3 locations in Alberta.

\begin{tabular}{|c|c|c|c|c|c|c|c|}
\hline \multirow[b]{2}{*}{ Location } & \multirow[b]{2}{*}{1977} & \multirow[b]{2}{*}{1978} & \multirow[b]{2}{*}{1979} & \multirow[b]{2}{*}{1980} & \multirow[b]{2}{*}{1981} & \multicolumn{2}{|c|}{$\begin{array}{c}\text { Long term } \\
\text { average' }\end{array}$} \\
\hline & & & & & & $\begin{array}{l}\text { Apr.- } \\
\text { Aug. }\end{array}$ & Annual \\
\hline Manyberries & 162 & 239 & 187 & 187 & 200 & 211 & 327 \\
\hline Stavely & 301 & 605 & 273 & 303 & 326 & 351 & 614 \\
\hline Kinsella & & & 220 & 417 & 148 & 285 & 432 \\
\hline
\end{tabular}

'Average precipitation for 30 years at Stavely and Manyberries and 18 years at Kinsella.

latter area was subject to chinook winds.

The Mixed Prairie site, situated at the Agriculture Canada Research Substation at Manyberries (185 km SE of Lethbridge), was typical of the Stipa-Bouteloua Faciation described by Coupland (1961). The soils were calcareous brown chernozemic (Aridic Haploboroll) and precipitation averaged $327 \mathrm{~mm}$.

In all experiments the material considered as mulch included the classes of fresh mulch and humic mulch while the standing dead plant litter included the accumulation of dead leaves and culms and represented cured herbage as described by Dyksterhuis and Schmutz (1947).

\section{Experiment 1}

Single sites were selected at the Stavely and Manyberries Research Substations which had been protected from grazing for about 30 years. At each site, plots $(2 \times 2 \mathrm{~m})$ were arranged in a matrix of 8 rows and 10 columns. Two contiguous rows were selected, systematically, in each year for treatment beginning in 1977,1978 , and 1979. All plots within each row were nested and treated identically. Plots in 1 row were treated as a control in the 
initial year of selection while plots in the other row had mulch and standing litter removed by raking in early spring while plants were dormant. Plots in the 2 remaining rows represented the control in 1980 and 1981 , respectively. The control plots had all mulch and standing litter removed at the time of harvest. Herbage yields in control and treated plots were estimated by harvesting $1-\mathrm{m}^{2}$ quadrats in the center of each plot in late September. The control plots were harvested once in the initial year of selection, while the treated plots were harvested in each year of the study. The forb and grass components were sorted and, together with the mulch/litter fraction, were dried and weighed.

Two methods were used to analyze the data. One method was to determine the trend of herbage yields in relation to frequency of defoliation. In this test, the frequency of defoliation was the main effect while the row, with nested plots, was the replicate. The main effect was partitioned into linear and quadratic components, each with $1 \mathrm{df}$, and tested using their interaction with replication as the error term ( $2 \mathrm{df})$. The number of replications was 3 , one for each year in which treatments were initiated in a row.

The year effect was removed prior to analysis by transforming the estimates of herbage yield to a proportion of yield of the control for that year. We assumed that yields from control plots were representative of potential site productivity for the year in which they were obtained.

In order to avoid using a control, a second method was used to show the impact of repeated dormant season defoliation on yield. Average yields were tabulated by the year in which they were harvested and by the number of harvest-years. No further analysis was attempted since the plots were nested within a row and each row represented a single number of harvest-years. The basis for comparison, therefore, was across rows (harvest-years) within the same year of harvest. Although this approach eliminated the year effect, it assumed that each row was representative of the site.

\section{Experiment 2}

A second study, consisting of 2 experiments, was conducted at Stavely to determine the first-year effects of removing standing dead plant litter on rough fescue plants. Individual plants, randomly selected for each treatment, represented the experimental unit.

In each experiment, the treatments consisted of defoliating 10 rough fescue plants by clipping at 5 or $15 \mathrm{~cm}$, or no disturbance (control). In the first experiment, plants were defoliated only in early spring (1982) for 3 treatments while in the second experiment, plants were defoliated in fall (1982) or spring (1983) for a total of 5 treatments. All treatments were imposed during plant dormancy. Mulch was removed within $20 \mathrm{~cm}$ from around the base of defoliated plants.

Treatment response was assessed in late summer following the first growing season after treatment by measuring plant circumference and height, harvesting the plants at ground level, separating old growth from new growth and determining dry matter, and counting tillers and determining their densities and weights. The data were analyzed using least squares analysis and single degree of freedom contrasts to test between specific treatments (Steel and Torrie 1980).

\section{Experiment 3}

Three sites were selected at Kinsella on grassland that had been protected from grazing for $\mathbf{3 0}$ years and from mowing for $\mathbf{8}$ years. At each site, plots were established in a $3 \times 3$ Latin square and treated by (1) removing standing dead plant litter and mulch, (2) removing standing dead plant litter and mulch and returning it to the plot, and (3) leaving the plot undisturbed (Control). Each plot was $2 \times 2 \mathrm{~m}$ and the standing dead plant litter was harvested with a Mott mower in late April in 1979, 1980, and 1981. The mower cut standing dead plant material $6 \mathrm{~cm}$ above the ground but the flailing action of the cutters picked up most of the mulch below that level. Tillers may have emerged by that time but green foliage was not removed by the mower.

The treatment effect was measured in August 1981, after cessation of plant growth. A 0.5- $\mathrm{m}^{2}$ quadrat was centrally located within each treatment plot. Species response to the treatments was measured from $5,100-\mathrm{cm}^{2}$ subplots in each quadrat. Tiller heights were determined in the field, the subplots were then harvested, the plant species separated, and tillers counted. This was followed by harvesting the entire quadrat by removing the standing dead plant litter and harvesting the herbage to ground level. The harvested material and litter were dried and weighed.

Tiller numbers of individual species were converted to a percentage for all species but, prior to analysis, the data were transformed by the square root. Percentages greater than 80 were subtracted from 100 before transformation as recommended by Steel and Torrie (1980). The data were analyzed using least squares analysis and contrasts were tested as before.

\section{Results}

\section{Experiment 1}

Litter and mulch yielded an average of $805 \mathrm{~g} / \mathrm{m}^{2}$ at Stavely and $57 \mathrm{~g} / \mathrm{m}^{2}$ at Manyberries in the initial year of treatment. Neither the linear nor quadratic trends of herbage yields, as a proportion of the control, with frequency of litter removal, were significant $(P>0.05)$ at either Stavely or Manyberries. However, at Stavely grass yields remained constant while forb yields tended to increase with increasing number of harvest-years while at Manyberries both grass and forb yields tended to decrease (Table 2).

Table 2. Herbage yields, as a proportion of the control $(\%)$, in relation to number of harvest-years at 2 locations $(n=30)$.

\begin{tabular}{lcccc}
\hline \hline Location & Harvest-years & Grass & Forbs & Total \\
\hline Stavely & 1 & 75 & 106 & 77 \\
& 2 & 74 & 123 & 76 \\
& 3 & 71 & 144 & 76 \\
Manyberries & SEM & 13 & 58 & 08 \\
& 1 & 75 & 56 & 72 \\
& 2 & 51 & 49 & 50 \\
& 3 & 44 & 42 & 43 \\
& SEM & 11 & 15 & 11 \\
\hline
\end{tabular}

Herbage yields, harvested the same year but representing different number of harvest-years, are shown in Table 3. At Stavely, combined grass and forb yields were greater following 2 years of harvesting than after 1 year. Yields, in 1980 and 1981, were virtually identical from plots harvested from 2 to 5 consecutive years. Yields of forb or grass types showed no consistent trends with number of harvest-years. Average grass and total herbage yields at Manyberries declined with increasing number of harvest-years.

\section{Experiment 2}

Rough fescue tillers were shorter $(P<0.05)$ the first year after removing litter and mulch at Stavely (Table 4). Plant heights were affected $(P<0.05)$ by the severity of removing standing dead plant litter but not by the season in which it was removed. Plant weight was not affected $(P<0.05)$ by the treatment. Removing standing dead plant litter also resulted in an increase $(P>0.05)$ in tiller density but a decrease $(P<0.05)$ in tiller weight.

\section{Experiment 3}

At Kinsella, clipping and removing litter resulted in a small $(P>0.05)$ increase in herbage yield (Table 5). However, a significant $(P<0.05)$ increase in yield was obtained when litter was replaced. The differences among treatments were contributed mostly by the forb component of the herbage. The proportion of rough fescue decreased $(P<0.05)$ from $82 \%$ in the control to $70 \%$ on clipped plots although total weight remained the same. Replacing mulch and litter, after clipping, yielded a recovery of less than 
Table 3. Herbage yields $\left(\mathrm{g} / \mathrm{m}^{2}\right)$ in relation to the number of harvest-years within the year of harvest ( $n=10$ plots nested within 1 row).

\begin{tabular}{|c|c|c|c|c|c|c|}
\hline \multirow[b]{2}{*}{ Stavely } & \multicolumn{2}{|c|}{$\begin{array}{c}\text { Year } \\
\text { harvested }\end{array}$} & \multicolumn{4}{|c|}{ No. of harvest-years } \\
\hline & & 1 & 2 & 3 & 4 & 5 \\
\hline Grasses & $\begin{array}{l}1978 \\
1979 \\
1980 \\
1981\end{array}$ & $\begin{array}{l}181 \\
108\end{array}$ & $\begin{array}{l}222 \\
106 \\
117\end{array}$ & $\begin{array}{l}121 \\
105 \\
127\end{array}$ & $\begin{array}{l}116 \\
103\end{array}$ & 127 \\
\hline Forbs & $\begin{array}{l}1978 \\
1979 \\
1980 \\
1981\end{array}$ & $\begin{array}{l}42 \\
12\end{array}$ & $\begin{array}{l}25 \\
29 \\
13\end{array}$ & $\begin{array}{l}34 \\
24 \\
24\end{array}$ & $\begin{array}{l}14 \\
47\end{array}$ & 24 \\
\hline Total & $\begin{array}{l}1978 \\
1979 \\
1980 \\
1981\end{array}$ & $\begin{array}{l}223 \\
120\end{array}$ & $\begin{array}{l}247 \\
135 \\
130\end{array}$ & $\begin{array}{l}155 \\
129 \\
151\end{array}$ & $\begin{array}{l}130 \\
150\end{array}$ & 151 \\
\hline \multicolumn{7}{|c|}{ Manyberries } \\
\hline Grasses & $\begin{array}{l}1978 \\
1979 \\
1980 \\
1981\end{array}$ & $\begin{array}{l}54 \\
50\end{array}$ & $\begin{array}{l}34 \\
32 \\
15\end{array}$ & $\begin{array}{l}22 \\
14 \\
25\end{array}$ & $\begin{array}{l}12 \\
25\end{array}$ & 21 \\
\hline Forbs & $\begin{array}{l}1978 \\
1979 \\
1980 \\
1981\end{array}$ & $\begin{array}{l}8 \\
4\end{array}$ & $\begin{array}{l}7 \\
4 \\
1\end{array}$ & $\begin{array}{l}2 \\
1 \\
2\end{array}$ & $\begin{array}{l}1 \\
3\end{array}$ & 2 \\
\hline Total & $\begin{array}{l}1978 \\
1979 \\
1980 \\
1981\end{array}$ & $\begin{array}{l}62 \\
54\end{array}$ & $\begin{array}{l}41 \\
36 \\
16\end{array}$ & $\begin{array}{l}24 \\
15 \\
27\end{array}$ & $\begin{array}{l}13 \\
28\end{array}$ & 23 \\
\hline
\end{tabular}

one-third that in the control. Most of the replaced litter was lost during the 3-year period (Table 5).

Total tiller density increased $((P<0.05)$ as a result of clipping and removing litter (Table 6). The proportion of rough fescue tiller decreased and sedge (Carex spp.) tillers increased $(P<0.05)$ when litter was replaced following removal (Table 6). Inflorescences of western porcupine grass increased $(P<0.05)$ and rough fescue decreased where litter was removed (Table 7).

Removing litter resulted in shorter tillers of rough fescue (Table 7) as did the effect of removing and replacing litter. Western porcupine grass tiller heights were not affected by the removal or removal and replacement of litter.

\section{Discussion}

Removing standing dead plant litter and mulch over a 3-year
Table 5. Herbage yields and utter present $\left(g / \mathrm{m}^{2}\right)$ after 3 consecutive years of treatment in the rough fescue (F. hallit) grasslands at Kinsella $(\overline{\boldsymbol{x}} \pm$ SEM, $n=9)$.

\begin{tabular}{lcccr}
\hline \hline Treatment & Grass & Forbs & Total & \multicolumn{1}{c}{ Litter } \\
\hline Control (1) & $142 \pm 10$ & $11 \pm 6$ & $152 \pm 8$ & $282 \pm 13$ \\
Clip/replace (2) & $149 \pm 9$ & $33 \pm 5$ & $182 \pm 7$ & $80 \pm 13$ \\
Clip/ remove (3) & $148 \pm 9$ & $19 \pm 5$ & $167 \pm 7$ & $14 \pm 13$ \\
Contrasts & & & & \\
\hline 1 vs 2 & NS & $*$ & $*$ & $*$ \\
I vs 3 & NS & NS & NS & $*$ \\
2 vs 3 & NS & NS & NS & $*$ \\
\hline${ }^{1}$ Contrasts not significant $(P>0.05)$. & & & \\
${ }^{*}$ Contrasts significant $(P<0.05)$. & & &
\end{tabular}

period resulted in marginally greater herbage yields in the Fescue Prairie but lower yields in the Mixed Prairie. There was no evidence that the trends of increasing or decreasing herbage yields continued beyond 3 years although it is possible that the species composition had not stabilized. In the Fescue Prairie at Kinsella, the increase in herbage yield after harvesting was largely the result of greater forb production.

Under more arid conditions in the Mixed Prairie at Manyberries, herbage yields were depressed to about $43 \%$ of the control plots over a 3-year period where litter was removed. Both grass and forb yields declined $(P>0.05)$. Although the differences in response between the Stavely and Manyberries sites were not examined, they were probably related to the moisture regime of each area and to the inhibition of growth by mulch and standing dead plant litter.

Removing litter in more xeric areas should induce a moisture deficit more readily than in mesic areas because infiltration of rainfall is less deep and roots are nearer to the soil surface. Consequently, water available to the plants would be lost more readily than where infiltration and rooting were deep. Although the large amounts of litter at Stavely $\left(805 \mathrm{~g} / \mathrm{m}^{2}\right)$ would substantially reduce evaporation, the effect on inhibiting plant growth was, apparently, more important. Weaver and Rowland (1952) found that similar quantities of litter removed in big bluestem (Andropogon gerardi Vitman) and switchgrass (Panicum virgatum $L$.) grassland reduced yields from 26 to $57 \%$. However, at Manyberries, the net effect of litter $\left(57 \mathrm{~g} / \mathrm{m}^{2}\right)$ was to enhance productivity, presumably through the conservation of soil moisture.

Although forbs contributed most to the increase in herbage yield following litter removal on Fescue Prairie at Kinsella, tiller density of grass also increased, suggesting improved production potential. The increase in total tiller density was offset by shorter and lighter tillers.

Tillering appeared to be stimulated within the first growing season after removing litter from rough fescue plants at Stavely

Table 4. The first year effect of removing mulch and standing dead plant litter on several morphological characteristics of rough fescue (F. seabrella) plants at Stavely $(\bar{x} \pm$ SEM, $n=9)$.

\begin{tabular}{|c|c|c|c|c|c|c|c|}
\hline \multicolumn{2}{|l|}{ Defoliation treatment } & \multicolumn{2}{|c|}{ Height (cm) } & \multicolumn{2}{|c|}{ Weight/plant (g) } & \multicolumn{2}{|c|}{ Tillers (1983) } \\
\hline Season & $\mathrm{Ht}(\mathrm{cm})$ & 1982 & 1983 & 1982 & 1983 & Number & Weight (mg) \\
\hline $\begin{array}{l}\text { fall } \\
\text { spring } \\
\text { fall } \\
\text { spring } \\
\text { Control }\end{array}$ & $\begin{array}{r}5 \\
5 \\
15 \\
15\end{array}$ & $\begin{array}{c}45 \pm 1.7 \\
\overline{-} \\
49 \pm 1.6 \\
60 \pm 1.9\end{array}$ & $\begin{array}{l}35 \pm 1.8 \\
38 \pm 1.9 \\
51 \pm 1.6 \\
50 \pm 2.0 \\
63 \pm 1.8\end{array}$ & $\begin{array}{c}32 \overline{ \pm} 4.0 \\
- \\
30 \pm 3.8 \\
34 \pm 4.4\end{array}$ & $\begin{array}{l}37 \pm 5.3 \\
32 \pm 5.6 \\
41 \pm 4.8 \\
43 \pm 5.8 \\
38 \pm 5.8\end{array}$ & $\begin{array}{l}232 \pm 36 \\
222 \pm 39 \\
246 \pm 33 \\
284 \pm 40 \\
168 \pm 37\end{array}$ & $\begin{array}{l}153 \pm 26 \\
146 \pm 28 \\
178 \pm 24 \\
153 \pm 28 \\
303 \pm 39\end{array}$ \\
\hline \multicolumn{8}{|l|}{ Contrasts } \\
\hline $\begin{array}{l}\text { Control vs others } \\
\text { Defoliation ( } 5 \mathrm{~cm} \text { vs } 15 \mathrm{~cm} \text { ) } \\
\text { Defoliation (spring vs fall) }\end{array}$ & & $\stackrel{*}{\mathbf{N S}^{2}}$ & NS & $\begin{array}{l}\text { NS } \\
\text { NS } \\
-\end{array}$ & $\begin{array}{l}\text { NS } \\
\text { NS } \\
\text { NS }\end{array}$ & $\begin{array}{l}\text { NS } \\
\text { NS } \\
\text { NS }\end{array}$ & $\begin{array}{c}* \\
\text { NS } \\
\text { NS }\end{array}$ \\
\hline
\end{tabular}

Treatment not applied in 1982.

${ }^{2}$ Contrasts not significant $(P>0.05)$.

*Contrasts significant $(P<0.05)$. 
Table 6. Total tiller density $\left(\mathrm{no} . / 500 \mathrm{~cm}^{2}\right)$ and proportion $(\%)$ of total tillers of major species after 3 consecutive years of treatment in the rough fescue $(F$. hallii) grasslands at Kinsella ( $\bar{x} \pm S E M, n=9)$.

\begin{tabular}{|c|c|c|c|c|}
\hline \multirow[b]{3}{*}{ Treatment } & \multirow[b]{3}{*}{ Total $/ 500 \mathrm{~cm}^{2}$} & \multicolumn{3}{|c|}{ Proportion percent of total } \\
\hline & & Rough fescue & Sedge & Western porcupine grass \\
\hline & & $\sqrt{100}-\%)^{1} \quad(\%)^{2}$ & $\sqrt{100-\% 1} \quad(\%)^{2}$ & $\sqrt{\%^{1}} \quad(\%)^{2}$ \\
\hline $\begin{array}{l}\text { Control (1) } \\
\text { Clip/replace (2) } \\
\text { Clip/remove (3) }\end{array}$ & $\begin{array}{l}198 \\
354 \\
474\end{array}$ & $\begin{array}{l}2.8 \pm 0.40(92) \\
4.1 \pm 0.37(83) \\
3.2 \pm 0.37(89)\end{array}$ & $\begin{array}{l}1.9 \pm 0.32(3.5) \\
2.8 \pm 0.29(8.1) \\
2.7 \pm 0.30(7.3)\end{array}$ & $\begin{array}{l}0.9 \pm 0.11(0.4) \\
0.8 \pm 0.10(0.2) \\
1.0 \pm 0.10(0.4)\end{array}$ \\
\hline \multicolumn{5}{|l|}{ Contrasts } \\
\hline $\begin{array}{l}1 \text { vs } 2 \\
1 \text { vs } 3 \\
2 \text { vs } 3 \\
\end{array}$ & $*$ & $\begin{array}{c}* \\
\text { NS }^{3} \\
\text { NS }\end{array}$ & $\begin{array}{c}* \\
\text { NS } \\
\text { NS }\end{array}$ & $\begin{array}{l}\text { NS } \\
\text { NS } \\
\text { NS }\end{array}$ \\
\hline
\end{tabular}

1Transformation applied prior to analyses.

2 Back transformed data in brackets.

${ }^{3}$ Contrasts not significant $(P>0.05)$.

* Contrasts significant $(P<0.05)$.

Table 7. Tiller heights (cm) and inforescences (no. $\left./ \mathrm{m}^{2}\right)$ of 2 grasses after 3 consecutive years of treatment in the rough fescue $(F$. hallit) grasslands at Kinsella $(\mathbf{n}=9)$.

\begin{tabular}{|c|c|c|c|c|}
\hline \multirow[b]{2}{*}{ Treatment } & \multicolumn{2}{|c|}{ Rough fescue } & \multicolumn{2}{|c|}{ Western porcupine grass } \\
\hline & Tiller height & Infloresences & Tiller height & Infloresences \\
\hline $\begin{array}{l}\text { Control (1) } \\
\text { Clip/replace (2) } \\
\text { Clip/remove (3) } \\
\text { SEM }\end{array}$ & $\begin{array}{c}38 \\
28 \\
26 \\
1.3\end{array}$ & $\begin{array}{l}8.1 \\
6.3 \\
2.9 \\
5.4\end{array}$ & $\begin{array}{c}25 \\
22 \\
19 \\
2.1\end{array}$ & $\begin{array}{r}1.1 \\
4.1 \\
10.4 \\
2.7\end{array}$ \\
\hline \multicolumn{5}{|l|}{ Contrasts } \\
\hline $\begin{array}{l}1 \text { vs } 2 \\
1 \text { vs } 3 \\
2 \text { vs } 3\end{array}$ & $\stackrel{*}{*}$ & $\begin{array}{l}\text { NS } \\
\text { NS } \\
\text { NS }\end{array}$ & $\begin{array}{l}\text { NS } \\
\text { NS } \\
\text { NS }\end{array}$ & $\begin{array}{l}\text { NS } \\
* \\
*\end{array}$ \\
\hline
\end{tabular}

'Contrasts not significant $(P>0.05)$.

*Contrasts significant $(P<0.05)$.

(Table 4) and Kinsella (Sinton 1980). Litter insulates the soil against incident radiation thereby reducing light and temperature at the soil surface. Tillering in grasses is affected by temperature and light (Langer 1963, Laude 1972) while the interaction between them is critical (Mitchell 1953). Factors which lead to greater surplus energy within the plant promote tillering (Langer 1963). Consequently, removing the shading effect of the litter should stimulate tillering.

Removing standing dead plant litter resulted in shorter plants. The cause for the effect was not clear but it was likely related to an altered microenvironment since photosynthetic tissue was not removed. Soil moisture deficit, higher soil temperature, and greater light intensity at the crown are all enhanced by removing standing dead plant litter and may affect leaf length.

The plant response to defoliation was the same whether the treatment was applied in spring or fall. However, the severity of standing dead plant litter removal, as indicated by the influence of litter replacement on height of defoliation, did affect response. Although replacing litter could not duplicate the amount or distribution of litter on undisturbed plots, the effect was to produce a response that was generally between that achieved by complete removal and no disturbance. An important exception was in the yield of forbs from each treatment (Table 5). Replacing litter increased forb yields, perhaps by suppressing the expansion of grasses. Evidently forbs, consisting primarily of prairie sage (Artemisia ludoviciana Nutt.), could take better advantage of conditions presented by the redistributed litter than could grass.

The results from the studies imply that dormant season grazing would have no negative effect on forage yield in the Fescue Prairie but, rather it might enhance plant vigor by stimulating tillering in grasses. In the Mixed Prairie, however, grazing during dormancy might be expected to decrease forage yields as a result of removing standing dead plant litter. Because of this reduction in yield, stocking rates in the Mixed Prairie should be based on forage yields from grazed areas. This reduction in yield from ungrazed ranges has also been shown by Lacey and Van Poollen (1981) and confirms earlier observations (Smoliak et al. 1985) that forage production on grazed fields is about $40 \%$ of that on ungrazed fields.

\section{Literature Cited}

Bailey, A.W., and M.L. Anderson. 1978. Prescribed burning of a FestucaStipa grassland. J. Range Manage. 31:446-449.

Coupland, R.T. 1961. A reconsideration of grassland classification in the Northern Great Plains of North America. J. Ecol. 49:135-167.

Dyksterhuis, E.J., and E.M. Schmutz. 1947. Natural mulches or "litter" of grasslands: with kinds and amounts on a southern prairie. Ecology 28:163-179.

Hopkins, H.H. 1954. Effects of mulch upon certain factors of the grassland environment. J. Range Manage. 7:255-258.

Johnston, A., and L.J. Bezenu. 1962. Chemical composition of range forage plants of the Festuca scabrella association. Can. J. Plant Sci. 42:105-115.

Johnston, A., and M.D. MacDonald. 1967. Floral initiation and seed production in Festuca scabrella Torr. Can. J. Plant Sci. 47:577-583.

Lacey, J.R., and H.W. Van Poollen. 1981. Comparison of herbage production on moderately grazed and ungrazed western ranges. J. Range Manage. 34:210-212.

Langer, R.H.M. 1963. Tillering in herbage grasses. Herb. Abst. 33:141-148.

Laude, H.M. 1972. External factors affecting tiller development, p. 146154. In: Younger, V.B. and C.M. McKell (eds.), The biology and utilization of grasses. Academic Press, New York.

Looman, J., and K.F. Best. 1979. Budd's Flora of the Canadian Prairie Provinces. Agr. Can. Publ. 1662.

Mitchell, K.J. 1953. Influence of light and temperature on the growth of ryegrass (Lolium spp.). II. The control of lateral bud development. Physiol. Plant 6:425-443.

Pavlick, L.E., and J. Looman. 1984. Taxonomy and nomenclature of rough fescues, Festuca altaica, $F$. campestris ( $F$. scabrella var. major), and $F$. hallii in Canada and the adjacent part of United States. Can. J. Bot. 62:1739-1749.

Penfound, W.M.T. 1964. Effects of denudation on the productivity of grassland. Ecology 45:838-845.

Sauer, R.H. 1978. Effect of removal of standing dead material on growth of Agropyron spicatum. J. Range Manage. 78:121-122.

Slnton, H.M.M. 1980. Effect of burning and mowing on Festuca hallii (Vasey) Piper, Festuca scabrella Torr. M.Sc. Thesis, Univ. of Alberta, Edmonton.

Smoliak, S., B.W. Adams, B.G Schuler, R.A. Wroe, S.G. Klumph, and W.D. Willms. 1985. Forage production on selected native prairie sites in southern Alberta. Res. Br. Agr. Can. Tech. Bull. 1985-3E. Lethbridge.

Steel, R.G.D, and J.H. Torrie. 1980. Principles and Procedures of Statistics: A Biometrical Approach. 2nd ed. McGraw-Hill Book Co., New York. 
Weaver, J.E., and N.W. Rowland. 1952. Effects of excessive natural mulch development, yield, and structure of native grassland. Bot, Gaz. 114:1-19.

Willms, W., A.W. Bailey, and A. McLean. 1980. Effects of clipping or burning on some morphological characteristics of Agropyron spicatum. Can. J. Bot. 58:2309-2312.
Willms, W.D., S. Smoliak, and J.F. Dormaar. 1985. Effects of stocking rate on a rough fescue grassland vegetation. J. Range Manage. $38: 220-225$. 